\title{
Genetic identification and restriction fragment length polymorphism (RFLP) based analysis of Myxovirus resistant gene (Mx) of chicken in Bangladesh
}

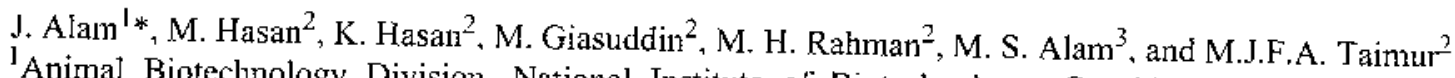
'Animal Biotechnology Division, National Institute of Biotechnology, Ganakbari, Ashulia, Savar. Dhaka-1341, Bangladesh. ${ }^{3}$ Goat and Sheep Product Bangladesh Livestock Research Institute, Savar, Research Institute, Savar, Dhaka-134 I, Bangladesh
\end{abstract}

\begin{abstract}
The Myxovirus resistant gene $(M x)$ codes for Mx protein with antiviral activity. $M x$ gene has been found in yeast and vertebrates ranging from fish to humans. In the present study $M x$ gene and its diversity in chicken is reported. A total of 42 blood samples were collected from different groups of chicken and were analyzed by polymerase chain reaction (PCR) and restriction fragment length polymorphism (RFLP). The diversity of $M x$ gene was enumerated by RFL.P of PCR product with Rsal and Sspl restriction enzyme. $M x$ gene was amplified from all the tested samples $(100 \%)$ with the primers used. The primers amplified specific $100 \mathrm{bp}$ and $300 \mathrm{bp}$ DNA fragments from $M x$ gene. RFLP analysis of PCR product obtained with mismatched primers revealed that three types of $M x$ gene allele are prevailing in the tested samples; these are'homozygous resistant Mx allelic gene $(\mathrm{R} / \mathrm{R})$, heterozygous $M x$ allelic gene $(\mathrm{R} / \mathrm{S})$ and homozygous sensitive $M x$ allelic gene (S/S). The proportions of each gene allele in the sampled chicken were $42.86 \% \mathrm{R} / \mathrm{R}, 42.86 \% \mathrm{~S} / \mathrm{S}$ and $14.29 \% \mathrm{R} / \mathrm{S}$. Interestingly, variation in $M x$ gene was observed within and between the groups of chicken. Present study has limitations like number of sample, species of bird sampled, etc. However, the study provides the genetic basis to some extent of chicken about resistance or sensitivity to avian influenza. To the best of our knowledge this is the first report of $M x$ gene related study in chicken in Bangladesh.
\end{abstract}

(Kcy Words: $M x$ gene, Diversity, Avian influenza, Chicken)

\section{Introduction}

The Myxovirus/avian influenza resistant $(M x)$ gene codes for a protein with antiviral activity. Mx protein, as an interferoninduced guanosine triphosphatase, confers resistant activity to Orthomvxovirus infection to some extent and has been found in many organisms including yeast (Rothman et al., 1990) and vertebrates ranging from fish to humans (Staeheli et al, 1989; Staeheli, 1990; Pavlovic and Staeheli, 1991; Bazzigher et al., 1993; Lee and Vidal, 2002; Plant and Thune, 2004). Human MxA has a wide spectrum of antiviral activity against Orthomyxoviruses including influenza viruses and Paramyxoviridae (Zürcher et al.,1992 and Zhao et al., 1996). Mouse $\mathrm{Mx} 1$ and $\mathrm{Mx} 2$ proteins can inhibit the influenza virus (Jin et al., 1999). The

*Corresponding Address: almjahan2003(@yahoo.com

Bang. J. Livs. Res. Vol. 20 (1 \& 2), 2013: P. 18-25, ISSN 1022-3851 
chicken $M x$ protein has been reported to exhibit antiviral activity against the influenza virus and the recombinant vesicular stomatitis virus (VSV). However,

- Benfield et al. (2008) reported that the breed Shamo, which has an Asparagine at amino acid 631 (Asn631) was void of activity against the $\mathrm{H} 5 \mathrm{~N} 1$ strain in primary chicken embryo fibroblasts (CEF) from an in vitro surrogate. The chicken $M x$ protein, which is composed of 705 amino acids and encoded by the $M x$ gene exists in predominantly cytoplasmic form (Bernasconi et al., 1995). Ko et al., (2002) reported that, among a number of naturally occurring mutations in the chicken $M x$ gene, only the Serine to Asparagine mutation at position 631 (S631N) caused by a single nucleotide polymorphism at position 2,032 ( $G$ to $A$ ) of $M x$ cDNA resulted in positively antiviral function in vitro. This advantageous allele $\mathrm{A}$ was detected in $50 \%$ of the breeds they studied. A single-point mutation of the $\mathrm{Mx}$ protein that could affect antiviral activity has also been reported in humans (Janzen et al, 2000). So, it is clear that variation in $M x$ gene is existing in population.

With the emergence of Highly Pathogenic Avian Influenza (HPAI) $\mathrm{H} 5 \mathrm{~N} 1$ in Bangladesh in 2007, stakeholders associated with animal and public health have become involved in different form of activities ranging from generating knowledge through scientific studies and implementation of the HPAI control program. Despite the efforts of the Government of Bangladesh, with the support of different development partners and stakeholders, $\mathrm{H} 5 \mathrm{N1}$ continues to circulate in Bangladesh. It seems that conventional control strategies based on surveillance, stamping out, movement restriction and enforcement of biosecurity measures did not prevent the HPAI outbreak. Moreover, a new clade 2.3.2.1 emerged in January 2011 resulting in further economic losses, and posing increased risk of human infection and potential threat of a human influenza pandemic (FAO, 2011). Detection of 2.3.2.1 clade from dead crows (Khan et $a l,, 2014)$ and the ongoing H5N1 outbreaks in poultry have substantiated that additional targeted influenza surveillance is warranted to fully characterize the dynamic influenza situation amongst livestock, wildlife, and people in Bangladesh. Experimental vaccination against $\mathrm{HPAI}$ is going on to control the disease. Therefore, alternative and complementary ways of controlling HPAI have to be explored. The use of antiviral chemotherapy and natural compounds, avian-cytokines, RNA interference, genetic breeding and/or development of transgenic poultry may be the options (Abdelwhab and Hafez 2012). $M x$ gene may be one of the candidates for development of influenza resistant poultry. Therefore, this very preliminary study was planned to determine the $M x$ gene and its diversity in chicken in Bangladesh.

\section{Material and Methods}

\section{Blood sample}

A total of 42 blood samples were collected from different groups of chicken. Blood samples were collected in anticoagulant, 
mixed well and transferred to the laboratory of Animal Health Research Division of Bangladesh Livestock Research Institute, Savar, Dhaka. All the samples were stored at $-80^{\circ} \mathrm{C}$ until used. The study was conducted during the period of July to December 2012.

\section{$D N A$ extraction}

The DNA was extracted from blood samples using the Phenol: chloroform: iso-amyl alcohol method. The extraction procedure is as follows: $200 \mu \mathrm{l}$ of blood was taken in a 1.5 $\mathrm{ml}$ micro centrifuge tube and $20 \mu \mathrm{l}$ of proteinase $\mathrm{K}$ was added and mixed well. To this, equal volume of Phenol: Chloroform: Iso-amyl alcohol (25:24:1) was added, then gently mixed and centrifuged at $8000 \mathrm{xg}$ for 2 minutes under refrigerated condition. The upper aqueous phase was transferred to a new micro centrifuge tube and above procedure was repeated. The upper aqueous phase was transferred to a new micro centrifuge tube and equal volume of chloroform was added, then gently mixed and centrifuged at $8000 \mathrm{xg}$ for 2 minutes under refrigerated condition. Three molar sodium acetate was added to one tenth of the volume of protein free DNA solution (upper aqueous phase) and two volumes of absolute ethanol was added and kept at $-80^{\circ} \mathrm{C}$ for one hour followed by centrifugation at $15000 \mathrm{xg}$ for 15 minutes. The DNA pellet was resuspended in $70 \%$ ethanol and centrifuged at $15000 \mathrm{xg}$ for 15 minutes and the DNA pellet was dried till no more ethanol left in the tube. DNA was suspended in $50 \mu 1$ of nuclease free water and stored at $-20^{\circ} \mathrm{C}$.

\section{Primer}

Two sets of primers were used to amplify the portion of $\mathrm{Mx}$ gene. Primer sequences with source and size of the PCR product are mentioned in Table 1. Primers were synthesized by BioBasic, Canada.

\section{Polymerase chain reaction (PCR)}

The PCR reaction mixture consisted of Genei red dye Master mix with enzyme 12.5 $\mu \mathrm{l}$, forward and reverse primer each $1 \mu 1$ (20pmole); template DNA $2 \mu 1$ and water 8.5 $\mu l$. The cycling profile comprised an initial denaturing step for $5 \mathrm{~min}$ at $94^{\circ} \mathrm{C}$, followed by 35 cycles at $94^{\circ} \mathrm{C}$ for $1 \mathrm{~min}, 60^{\circ} \mathrm{C}$ for 1 $\mathrm{min}$, and $72^{\circ} \mathrm{C}$ for $1 \mathrm{~min}$, and a final extension at $72^{\circ} \mathrm{C}$ for $5 \mathrm{~min}$ (Seyama et al., 2006). Specific condition was used for other primer (Sironi et al, 2010). Amplicons were analyzed by gel electrophoresis in a $2 \%$

Table 1. Primer sequences and their sources

\begin{tabular}{lcl}
\hline \multicolumn{1}{c}{ Primer sequence 5'-3' } & $\begin{array}{c}\text { PCR Product } \\
\text { size }\end{array}$ & \multicolumn{1}{c}{ Source } \\
\hline NE-F2: CCTTCAGCCTGTTTTTCTCCTTTTAGGAA & $100 \mathrm{bp}$ & $\begin{array}{l}\text { Seyama } \text { et } \\
\text { al. }(2006)\end{array}$ \\
NE-R2/R: CAGAGGAATCTGATTGCTCAGGCGTGTA & & \\
NE-R2/S:CAGAGGAATCTGATTGCTCAGGCGAATA & & Sironi et al: \\
$M x$-Sironi-F: GCACTGTCACCTCTTAATAGA & $299 \mathrm{bp}$ & $(2010)$ \\
$M x$-Sironi-R: GTATTGGTAGGCTTTGTTGA & & \\
\hline
\end{tabular}


agarose gel using Tris-acetate-EDTA (TAE) buffer and stained with ethidium bromide, and was finally visualized using transilluminator.

\section{Restriction fragment length polymorphism (RFLP)}

The PCR products obtained using NE-F2 and NE-R $2 / R$ primers were digested with the restriction endonuclease Rsal (Biolabs, USA) and those obtained using NE-F2 and NE-R2/S primers were digested with SspI (BioLabs, USA). The digestion reaction $(10 \mu 1)$ consisted of nuclease free water $3 \mu \mathrm{l}$, compatible $10 \mathrm{X}$ buffer $1 \mu \mathrm{l}$, specific restriction enzyme $1 \mu 1$ and PCR product $5 \mu \mathrm{l}$. The reaction mixture was incubated at $37^{\circ} \mathrm{C}$ water bath for 1hour. Upon digestion the products were electrophoresed in $3 \%$ agarose gel containing ethidium bromide. DNA was visualized with UV transilluminator (Daihan Scientific Co. Ltd., Korea).

\section{Results}

\section{Amplification of Mx gene with mismatched primer}

A total of 42 blood samples from different groups of chicken were investigated to determine the Mx gene and its diversity. By the mismatched primers $100 \mathrm{bp}$ fragment of DNA was amplified from Mx gene of all the tested samples $(n=42 / 42)$. Figure 1 represents the amplification of $100 \mathrm{bp}$ DNA from $\mathrm{Mx}$ gene of different samples. The primer set NE2-F2/F and NE2-R2/R amplified 100bp DNA from Mx gene
(Figure. 1 Left panel 1-5). On the other hand, the primer set NE-F2 and NE-R2/S was also amplified 100bp DNA from Mx gene (Figure 1 Right panel 1-5).

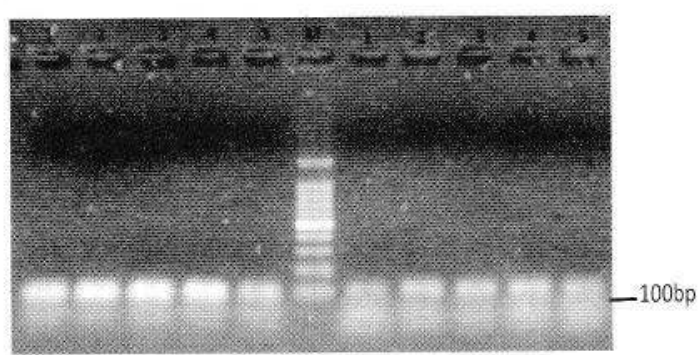

Figure 1. Amplification of Mx gene by PCR. Lane 1-5 (left): Amplification by primer NE-F2 \& NE-R2/R, Lane M: Marker, Lane 1-5(right): Amplification by primer NE-F2 and NE-R2/S

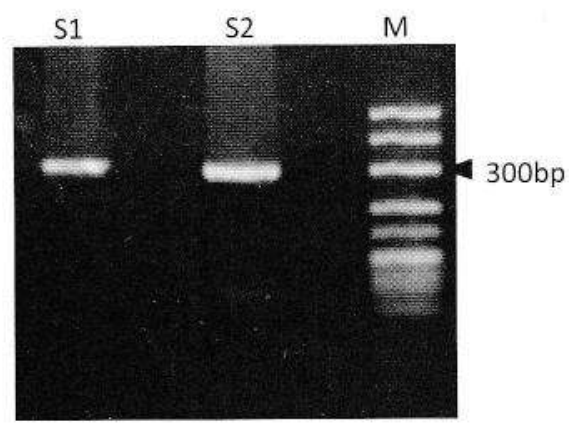

Figure 2. Amplification of Mx gene by Sironi's primer. Lane S1 and S2 : Test sample, Lane M: Marker

\section{Amplification of Mx gene}

DNA extracted from blood was subjected to PCR with primer reported earlier (Sironi et al., 2010). About 299bp DNA fragment was amplified from $100 \% \quad(n=42 / 42)$ tested samples. Figure 2 shows the amplification of $\sim 299$ bp DNA from $M x$ gene. 


\section{Diversity of Mx gene}

PCR products obtained with NE-F2 \& $\mathrm{NE}-\mathrm{R} 2 / \mathrm{R}$ primer were digested with restriction enzyme RsaI while PCR products obtained with NE-F2 and NE-R2/S were digested with SspI. Both the enzymes cut the $100 \mathrm{bp}$ fragment into two 73 and $27 \mathrm{bp}$ length fragments. Three types of results were observed (Figure 3) with each restriction enzyme. These are complete digestion $(42.86 \%)$, partial digestion (14.29\%) and no digestion ( $42.86 \%$ ). Complete, partial and no digestion with $S_{s p} \mathbf{I}$ indicate resistant (homozygous), variable (heterozygous) and sensitive (homozygous) to influenza, respectively. While complete, partial and no digestion with $R s a$ I indicate sensitive (homozygous) variable (heterozygous) and resistant (homozygous), to influenza, respectively. Because if the variation at nucleotide position 2032 is $\mathrm{G}$, which corresponds to the sensitive type, Rsal will digest the PCR product obtained using the NE-R2/R primer to fragments of both 73 and $27 \mathrm{bp}$, but SspI will not. Conversely, if the variation is $\mathrm{A}$, which coincides with the resistant type, $S s p$ I will digest the PCR product obtained using the NE-R2/S primer to fragments of 73 and 27 bp, but RsaI will not.

\section{Discussion}

Chickens are natural host of many viruses including influenza virus (Easterday, 1975) and infection with these viruses causes serious illness or death in chickens. The avian influenza virus (AIV) is also infectious to humans and has led to an acute condition in some cases (Subbarao et al., 1998). Selective breeding of virus-resistant chickens would be benefecial for both the livestock industry and human health. $\mathrm{Mx}$ protein induced by type I IFN is known to inhibit the multiplication of various viruses, including influenza virus (Lec and Vidal. 2002). Chicken $M x$ was first reported in a breed of German White Leghom (Bernasconi et al,, 1995), but it lacked antiviral activity for both influenza virus and vesicular stomatitis virus (VSV). However. it is reported that a specific amino acid substitution between Asn and Ser at position 631 determines the differential antiviral activity of chicken $M x$ protein (Ko et al., 2002). In the present study we endeavor to detect $M x$ gene followed by its diversity. The primers used in this study were found suitable for amplification of $M x$ gene. All the tested samples were amplified by the primer sets used (Figure 1,2 and Table 1). Our finding is comparable with the findings of Seyama et al., (2006) who designed and used this primer to detect and identify the $M x$ gene diversity in chicken. They tested 271 samples and specific band was found in $100 \%$ cases. Similar findings were reported earlier (Sartika et al., 2011; Elfidasari et al., 2013). Sironi et al. (2010) reported that among the primers designed by them, the forward primer anneals to the last intron of the $\mathrm{Mx}$ gene and the reverse primer anneals to the last axon on the gene. The $M x$ gene has a large number of repeat sequences making sequencing of the gene, genotyping error-prone (Sheila Ommeh, personal communication, International Livestock 
Research Institute, Nairobi, Kenya). Therefore, genotyping should be performed preferably using different primer sets (Sironi et al., 2010). In this study we used two restriction enzymes to do genotyping. However, we did not use restriction enzyme Hpy8I used by Sironi et al. (2010). Based on two restriction enzyme analysis, tested samples were genotyped into three groups namely, homozygous resistant, homozygous sensitive and heterozygous (Table 2 and Figure 3 ). Our findings comply with the findings of Seyama et al. (2006), who investigated 271 DNA of commercial and indigenous chickens from different sources and found resistant, sensitive and heterozygous $\mathrm{Mx}$ gene allele within and between the groups of chicken. Similar results were also reported by Sartika et al., (2011) and Sulandari et al.,(2009). They also reported that indigenous chicken has more frequency of resistant type $M x$ gene allele. Findings of the present study regarding distribution of $\mathrm{Mx}$ gene have likeness with the findings of Seyama et al., (2006). Overall they reported $33.95 \%(\mathrm{n}=92 / 271)$ resistant, $52.40 \%(n=142 / 271)$ sensitive and $13.65 \%$ $(n=37 / 271)$ heterozygous allele in the tested samples $(\mathrm{n}=271)$.

\section{Conclusion}

PCR-RFLP study of Mx gene in chicken revealed that three types of $\mathrm{Mx}$ gene viz., homozygous resistant (R/R), heterozygous $(\mathrm{R} / \mathrm{S})$ and homozygous sensitive $(\mathrm{S} / \mathrm{S}) \mathrm{Mx}$ allelic gene exists in tested chickens. The

Table 2. Diversity of $M x$ gene in chicken

\begin{tabular}{lllll}
\hline Chicken & \multicolumn{3}{c}{ PCR-RFLP } \\
\cline { 2 - 5 } & $\mathrm{R} / \mathrm{R}$ & $\mathrm{S} / \mathrm{S}$ & $\mathrm{R} / \mathrm{S}$ & Total \\
\hline Group 1 & 4 & 3 & 2 & 9 \\
Group 2 & 5 & 4 & 1 & 10 \\
Group 3 & 3 & 4 & 2 & 9 \\
Group 4 & 3 & 3 & 0 & 6 \\
Group 5 & 3 & 4 & 1 & 8 \\
Total & 18 & 18 & 6 & 42 \\
Total (\%) & 42.86 & 42.86 & 14.29 & 100 \\
\hline
\end{tabular}

R/R:Homozygous resistant; R/S: Heterozygous; S/S: Homozygous sensitive

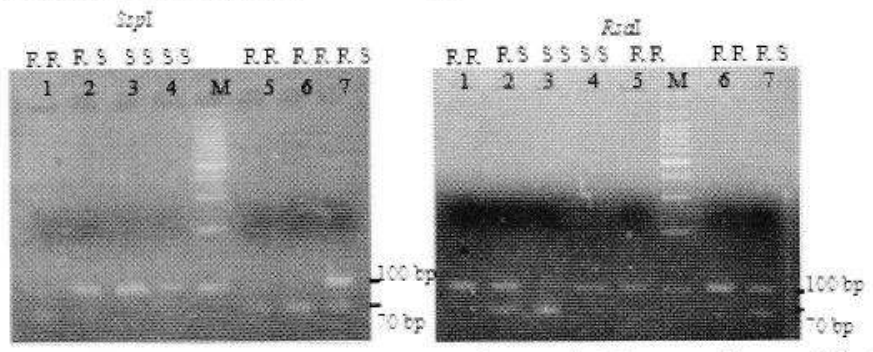

Figure 3. Restriction enzyme analysis of Mx gene. Left panel: Mx gene is amplified with primer NE-F2 and NE-R2/S and digested with Sspl. Right panel: Mx gene was amplified with NE-F2 and NE-R2/R and digested with RsaI. M: Marker, R/R: Homozygous resistant, S/S: Homozygous sensitive and R/S: Heterozygous 
proportion of each gene allele in the sampled chicken was $42.86 \%(\mathrm{R} / \mathrm{R}), 42.86 \%(\mathrm{~S} / \mathrm{S})$ and $14.29 \%(\mathrm{R} / \mathrm{S})$. The present study has limitations like number of sample, species of chicken sampled, etc. However, these findings provide the genetic basis to some extent of chicken about resistance or sensitivity to avian influenza. Further study with large number of samples covering various species of chicken is necessary to assess the diversity of Mx gene.

\section{References}

Abdelwhab, E.M. and Hafez, H.M. 2012. Insight into alternative approaches for control of avian influenza in poultry, with emphasis on highly pathogenic H5N1. Viruses, 4: 3179-3208.

Bazzigher, L., Schwarz, A. and Staeheli P. 1993. No enhanced influenza virus resistance of murine and avian cells expressing cloned duck Mx protein. Virology. 195:100-112.

Benfield, C.T.O., Lyall. J.W., Kochs. G. and Tiley LS. 2008. Asparagine 631 variants of the chicken $\mathrm{Mx}$ protein do not inhibit influenza virus replication in primary chicken embryo fibroblasts of in vitro surrogate assays. J. Virol. 82:7533-7539.

Bernasconi, D., Schultz, U. and Staeheli P. 1995. The interferon induced $\mathrm{Mx}$ protein of chickens lacks antiviral activity. J Interferon Cytokine Res. 15:47-53.

Elfidasari, D., Duryadi Solihin, D., Soejoedono, R.D. and Murtini, S. 2013. Identification of gene resistance to avian influenza virus (Mx gene) among wild waterbirds. Makara Journal of Science 17/1: 6-10
Easterday, B.C. 1975. Animal influenza. In: The Influenza Viruses and Influenza (Ed. By ED Kilbourne), New York. Academic Press. Pp. 449-481.

Food and Agricultural Organization (2011) H5NI HPAI Global Review - April to June, 2011. Issue no. 28 (http//Www fao.org: docrep/014/am 722e/am722e00.pdf). Accessed on 03.05.2015.

Janzen, C., Kochs, G. and Haller O. 2000. A monomeric GTPase negative $\mathrm{MxA}$ mutant with antiviral activity. J. Virol. 74: 8202-8206.

Jin, H.K., Takada, A., Kon, Y., Haller, O. and Watanabe T. 1999. Identification of the murine $\mathrm{Mx} 2$ gene: Interferon-induced expression of the $\mathrm{Mx} 2$ protein from the feral mouse gene confers resistance to vesicular stomatitis virus. J. Virol. 73:4925-4930.

Khan, S.U., Berman, L., Haider. N.. Gerloff. N., Rahman, M.Z., Shu. B., Rahman. M.. Dey, T.K., Davis, T.C.. Das. B.C., Balish. M.. Islam, A., Teifke, J.P.. Zeidner, N.. Lindstrom. S., Klimov, A., Donis. R.O., Luby, S.P., Shivaprasad, H.L. and Mikolon, A.B. 2014. Investigating a crow die-off in January- February 2011 during the introduction of a new clade of highly pathogenic avian influenza virus $\mathrm{H} 5 \mathrm{~N} 1$ into Bangladesh. Archives of Virology. 159: 509-518.

Ko, J. H., Jin, H. K., Asano, A., Takada, A., Ninomiya, A., Kida, H., Hokiyama, H., Ohara, M., Tsuzuki, M., Nishibori, M., Mizutani, M. and Watanabe, T. 2002. Polymorphisms and the differential antiviral activity of the chicken Mx gene. Genome Res. 12:595-601. 
Lee, S.H. and Vidal, SM. 2002. Functional diversity of $\mathrm{Mx}$ proteins: Variations on a theme of host resistance to infection. Genome Res. 12:527-530.

Rothman, J.H., Raymond, C.K.. Gillbert, T., O'Hara, P. J. and Stevens, T. H. 1990. A putative GTP binding protein homologous to interferon-inducible $\mathrm{Mx}$ proteins performs an essential function in yeast protein sorting. Cell. 61:1063-1074.

Pavlovic, J. and Staeheli, P. 1991. The antiviral potentials of $\mathrm{Mx}$ proteins. $\mathrm{J}$. Interferon Cytokine Res. 11:215-219.

Plant, K.P. and Thune, R.L. 2004. Cloning and characterization of a channel catfish Ictalurus punctatus $\mathrm{Mx}$ gene. Fish Shellfish Immunol. 16:391-405.

Sartika, T., Sulandar, S., Syamsul, M. and Zein, A. 2011. Selection of Mx gene genotype as genetic marker for Avian Influenza resistance in Indonesian native chicken. BMC Proceedings 2011, 5 (Suppl 4):\$37.

Seyama, T., Ko, J.H., Ohe, M., Sasaoka, N., Okada, A., Gomi, H., Yoneda, A., Ueda, J., Nishibori, M., Okamoto, S., Maeda, Y. and Watanabe, T. 2006. Population research of genetic polymorphism at amino acid position 631 in chicken $\mathrm{Mx}$ protein with differential antiviral activity. Biochem. Genet. $44: 437-448$

Sironi, L., Ramelli, P., Williams, J.L. and Mariani, P. 2010. RFLP Genotyping protocol for chicken $\mathrm{Mx}$ gene G/A polymorphism associated with the $\mathrm{S} 631 \mathrm{~N}$ mutation. Genetics and Mol. Res. 9: 1104-1108
Staeheli, P.. Yu, Y. X. and Grob, R. 1989. A double-stranded RNA-inducible fish gene homologous to the murine influenza virus resistance gene Mx. Mol. Cell. Biol. 9:3117-3121.

Staeheli, P. 1990. Interferon-induced proteins and the antiviral state. Adv. Virus Res. $38: 147-200$.

Subbarao, K., Klimov, A., Katz, J., Regnery, H., Lim, W., Hall, H., Perdue, M., Swayne, D., Bender, C.. Huang, J, Hemphill, M. Rowe, T., Shaw, M., Xu, X., Fukuda, K. and Cox, N. 1998. Characterization of an avian influenza A (H5N1) virus isolated from a child with a fatal respiratory illness. Science. 279, 393-396.

Sulandari, S., Syamsul Arifin Zein, M., Astuti, D. and Sartika, T. 2009. Genetic polymorphisms of the chicken antiviral $\mathrm{Mx}$ gene in a variety of Indonesian indigenous chicken breeds. J. Veteriner., 10: 50-56.

Zhao, Y., Nichols, J.E., Valdez, R., Mendelson, C. R. and Simpson, E. R. 1996. Tumor necrosis factor- $\infty$ stimulates aromatase gene expression in human adipose stromal cells through use of an activating protein-1 binding site upstream of promoter 1.4. Mol. Endocrinol. 10 (11):1350-1357.

Zürcher, T., Pavlovic, J. and Staeheli, P. 1992. Mechanism of human MxA protein action: Variants with changed antiviral properties. EMBO J. 11:1657-1661. 